\title{
A Guide to Round 2 of the Stimulus
}

\section{David Deeds (University of St. Thomas)} KEYWORDS: Management, Finance, crisis
management.

On April 24, 2020 President Trump signed the second tranche of small business loans into law, providing $\$ 310$ billion more for the Paycheck Protection Program (PPP) and $\$ 60$ Billion for the Economic Injury Disaster Loans (EIDL). This new round of funding (https://www.forbes.com/sites/advisor/2020/04/22/the-s enate-approved-more-funding-for-the-paycheck-protecti on-program-heres-what-you-need-to-

know/\#2e627f940848) includes provisions aiming to funnel financial assistance to smaller businesses initially shut out of loans.

The law sets aside $\$ 60$ billion for small- and mediumsized community banks and credit unions and less traditional lending companies that are Small Business Association-approved. Both the PPP and EIDL programs will continue to be administered via the SBA and the loans will be handled through banks, but they will also be handled through non-bank fin-tech companies like Paypal, Kabbage, Intuit and others.

So, if you didn't get either of these loans the first time around, get your application in now. Below I will provide details on each program, including what they are, what they can be used for, and terms.

\section{Paycheck Protection Program Loans (PPP Loans)}

PPP loans are designed to enable small businesses to keep employees on payroll. The PPP loans are available for up to 2.5 times your average monthly payroll for the year preceding your application. These loans will be forgiven if all workers stay employed for eight weeks and if the funds are used for payroll, rent, mortgage interest or utilities. Any portion of loans not forgiven will be treated as a two-year loan with a $1 \%$ fixed interest rate, and payments will be deferred for 6 months (however, interest will continue to accrue over this period).

You can qualify for PPP loans if your small business:
- was operational as of February 15, 2020

- has 500 employees or less, regardless of revenue

- is a sole proprietorship, does independent contracting or if you are a self-employed individual that regularly carries on any trade or business (including in the "gig economy")

- is a non-profit entity under Section 501(c)(3) as long as it has 500 employees or less

- is a tribal business that meets the SBA's size requirements

In regards to loan forgiveness, the SBA has provided the following information:

- Loan forgiveness is based on how the loan money is used over an 8-week period, beginning on the date the lender makes the first disbursement of the loan.

- The actual amount of loan forgiveness is determined based on certain costs incurred and payments made during the covered period. Payroll costs are the main cost eligible for forgiveness under the PPP, but there are others.

\section{Payroll costs that are eligible for loan forgiveness:}

- Salary, wages, commission or similar compensation (recent SBA guidance states that payroll costs include all cash compensation, including a housing stipend or allowance)

- Payments for vacation, parental, family, medical or sick leave

- Allowance for dismissal or separation

- Payments for the provision of group health care benefits, including insurance premiums

- Payments for retirement benefits

- State or local payroll taxes

Payroll costs that are not eligible for loan
Copyright @ 2020 The Authors. Entrepreneur \& Innovation Exchange is published at EIX.org. This is an open access article under the terms of the Creative Commons Attribution-NoDerivs License, which permits use and distribution in any medium, provided the original work is properly cited and no modifications or adaptations are made. View EIX.org Authorship Terms at https://eix.org/terms FamilyBusiness 


\section{forgiveness:}

- Payments to an independent contractor

- Cash compensation in excess of $\$ 100,000$

- The employer's share of federal payroll taxes

- Qualified sick leave and qualified parental leave wages for which credit is allowed under the Families First Coronavirus Response Act (FFCRA)

\section{Non-payroll costs which are eligible for loan forgiveness:}

- Interest payments on a mortgage incurred in the ordinary course of business on real or personal property and that was in existence on Feb. 15, 2020

- Rent payments under leasing agreements in existence on Feb. 15, 2020

- Utility payments for electricity, gas, water, transportation, telephone or internet for which service was in existence on Feb. 15, 2020

It is important for businesses to consider strategies for maximizing loan forgiveness, while also balancing their short-term and long-term needs. In some situations, it may be more beneficial to continue furloughs or other workforce reductions in the short-term, and pay back any unforgiven loan amount over time at a low interest rate. Other businesses may take steps to increase payroll costs during the covered period by rehiring employees and providing incentive bonuses.

There are some limitations on loan forgiveness:

- Not more than 25 percent of the loan forgiveness amount can be attributable to nonpayroll costs (i.e., mortgage interest, rent and utilities).

- Proceeds from any advance up to $\$ 10,000$ on an Economic Injury Disaster Loan (EIDL) will be deducted from the loan forgiveness amount.

- Additionally, the loan forgiveness amount will be reduced if the business has reduced its number of full-time equivalent (FTE) employees or has reduced the salary or wages of certain employees.

The terms of PPP Loans are:
- The principal amount of the PPP loan and any accrued interest that is not forgiven will continue as a loan on its original terms, including:

- A maturity date which is two years from the date of disbursement

- No payments during the first six months

- An interest rate of one percent per annum

- No prepayment penalty (prior notice of prepayment may be required if the loan has been sold on the secondary market).

\section{Economic Injury Disaster Loans (EIDL)}

EIDL loans are up to $\$ 2$ million. A personal guarantee is waived for EIDLs up to $\$ 200,000$ through the end of the year, while EIDLs of $\$ 25,000$ or less require no collateral. However, the SBA has created an emergency grant advance for up to $\$ 10,000$ to quickly help businesses that need the money faster due to impacts of COVID-19. The SBA states that the advances will take as little as three days.

The emergency grant advances will help small businesses overcome any temporary revenue loss as a result of COVID-19 and will not have to be repaid if used for certain business expenses. The amount of the advance depends on the number of employees (at $\$ 1,000$ per employee).

You qualify for an EIDL if your business:

- has 500 employees or fewer.

- has more than 500 employees but meets the SBA's industry size standards (https://www.sba.gov/sites/default/files/2019-08/ SBA\%20Table\%20of\%20Size\%20Standards_E ffective\%20Aug\%2019\%2C\%202019_Rev.pdf) for this pandemic.

- is organized for profit.

- operates primarily in the U.S. or contributes significantly to the U.S. economy through taxes or use of U.S. products, materials or labor.

- is independently owned and operated.

- is not a dominant business in its field nationally.

- is a private non-profit organization.

- is a $501(\mathrm{c})(19)$ veteran organization.

You can apply for an EIDL directly on the SBA's website no later than December 16, 2020, (or December 21, 2020 , in some states). Do not delay your application, as 
funds are granted on a first-come, first-served basis.

The first thing you'll see is a disclosure, which describes the loan in detail and states your information is only collected for eligibility purposes. You'll then be asked to provide the following information for each owner with a $20 \%$ stake or more:

- Social Security Number

- Birthdate

- Birthplace

- Citizenship status

- Street address

You'll also be asked for additional information, such as any criminal charges against any of the owners. Before you submit, click the box that states you wish to be considered for up to $\$ 10,000$ advance. Funds can be directly deposited into your account. The advance will be forgiven if it is spent on paid leave, maintaining payroll, mortgage or lease payments.

EIDL applications must include the following:

- Documentation verifying the number of FTE employees on the payroll and pay rates for the covered period and the prior periods included in the formulas for determining any reduction in loan forgiveness, including payroll tax filings reported to the Internal Revenue Service and state income, payroll and unemployment insurance filings

- Documentation, including cancelled checks, payment receipts, transcripts of accounts or other documents verifying payments on mortgage obligations, rent payments and utility payments

- A certification from a representative of the business authorized to make such certifications that: The documentation presented is true and correct; and The amount for which forgiveness is requested was used to retain employees, make interest payments on a covered mortgage obligation, make payments on a covered rent obligation or make utility payments

- Any other documentation SBA determines necessary

\section{Keep detailed records}

It will be important for businesses to keep detailed records regarding the use of PPP loans and EIDL loans.
You should start keeping detailed records beginning on day one. You might consider keeping PPP loan and EIDL loan proceeds in a separate bank account, with only costs eligible for loan forgiveness paid out of that account. Good record-keeping will be a key to loan forgiveness.

The PPP and EIDL programs have funds available, and new restrictions and new lenders should make it easier for your business to access these loans. So if you haven't applied, get it done. The government is providing what are in essence grants to your business that do not require repayment if used properly and the uses are properly documented. 